\title{
Angiosarcoma w obszarze napromienianym po 16 latach obserwacji u chorej na raka piersi leczonej oszczędzająco — analiza przypadku
}

\author{
Zbigniew Jodkiewicz¹ , Barbara Kozakiewicz , \\ Katarzyna Roszkowska-Purska², Barbara Trzaska ${ }^{1}$
}

Opisano przypadek angiosarcoma w obszarze napromienianym u 71-letniej chorej leczonej z oszczędzeniem piersi przed 16 laty z powodu raka piersi lewej. Należy on do rzadkich nowotworów tkanek miękkich i stanowi ok. 1-2\% wszystkich typów mięsaków. W obszarze napromienianym z powodu raka piersi występuje jeszcze rzadziej i stwierdza się go zaledwie u 0,04\% chorych. Dokonano analizy przebiegu choroby oraz przeglądu piśmiennictwa z uwzględnieniem sposobów leczenia oraz czynników rokowniczych.

\section{Angiosarcoma in an irradiated area after 16 year follow-up in patient treated with breast conserving therapy - case report}

A case is described of angiosarcoma in the irradiated area in a 71 year old patient treated with breast conserving therapy 16 years ago for cancer of the left breast. These rare tumours of soft tissues account for about $1-2 \%$ of all types of sarcomas. In the irradiated area breast cancer occurs less often and is found only in $0.4 \%$ of patients. An analysis of the course of the disease, and review of literature with regard to methods of treatment and prognostic factors were carried out.

NOWOTWORY Journal of Oncology 2014; 64, 5: 396-400

Słowa kluczowe: angiosarcoma w obszarze napromienianym, powikłanie po radioterapii

Key words: angiosarcoma in an irradiated area, complication of radiotherapy

\section{Wstęp}

Zachorowania na mięsaki w Polsce szacuje się na 2/100 000/rok, co w liczbach bezwzględnych oznacza około 800 nowych zachorowań rocznie. Naczyniakomięsaki (angiosarcoma - AS) to jedne z najrzadziej występujących typów mięsaków tkanek miękkich u dorosłych, stanowią one ok. 1-2\% wszystkich mięsaków. Surowy współczynnik zachorowalności w Europie wynosi około 0,31/100 000/rok [1], natomiast AS po radioterapii z powodu raka piersi jest jeszcze rzadszym nowotworem i stanowi 0,04\% złośliwych nowotworów piersi. W ocenie Holenderskiego Rejestru Nowotworów rozpoznawany jest w $0,05-0,16 \%$ przypadków [2].
Celem pracy jest analiza przebiegu rzadkiego nowotworu o typie angiosarcoma w obszarze napromienianym po wieloletniej obserwacji u chorej na raka piersi lewej leczonej z oszczędzeniem piersi, z uwzględnieniem sposobów leczenia oraz potencjalnych czynników rokowniczych.

\section{Opis przypadku}

Chora lat 54 do chwili zachorowania na raka piersi nieleczona z powodu innych chorób. Nie rodziła, 3-krotnie dokonywała aborcji, menopauza w 52 rż. Przez 2 lata przed rozpoznaniem raka piersi przyjmowała hormonalną terapię zastepczą w postaci klimonormu 1 tabl./dz. (estradiolum $2 \mathrm{mg}$ + levonorgestrelum 0,15 mg). Wśród krewnych pierw-

${ }^{1}$ Zakład Teleradioterapii

2Zakład Patologii Nowotworów

Centrum Onkologii — Instytutu im. Marii Skłodowskiej-Curie w Warszawie 
szego stopnia nie obserwowano zachorowań na nowotwory złośliwe. W dniu 22 maja 1996 r. wykonano amputację radykalną piersi prawej sposobem Pateya w szpitalu rejonowym. W badaniu mikroskopowym stwierdzono utkanie raka zrazikowego. W zbadanych 20 węzłach chłonnych pachy nie znaleziono przerzutów (pT2N0M0). Pacjentka została poddana ścisłej obserwacji.

Po 9 miesiącach w dniu 28 lutego 1997 r. u chorej rozpoznano metachronicznego raka piersi lewej w klinicznym stopniu zaawansownia T1N0M0 i zastosowano leczenie oszczędzające (BCT — breast conserving therapy). W badaniu mikroskopowym stwierdzono ponownie utkanie raka zrazikowego bez przerzutów w węzłach chłonnych pachy. Z tego powodu chora została zakwalifikowana do uzupełniającej radioterapii z pól zewnętrznych (EBRT - external beam radiotherapy) na obszar piersi lewej. W okresie od 9 kwietnia do 15 maja 1997 r. była napromieniana przy użyciu Co60 z 2 pól tangencjalnych na okolicę piersi lewej, otrzymując dawkę 5000 cGy/t w 25 frakcjach, następnie w okresie 19-27 maja 1997 r. napromieniana dodatkowo na lożę po usuniętym guzie elektronami o energii $12 \mathrm{MeV}$ do dawki 1500 cGy/t w 6 frakcjach. Tolerancja leczenia była dobra, nie obserwowano powikłań. Odczyn skórny popromienny został oceniony na I stopień wg klasyfikacji EORTC/ /RTOG.

Po ukończonej EBRT u chorej w dniu 4 lipca 1997 r. wykonano rekonstrukcję piersi prawej z użyciem protezy, następnie od dnia 15 lipca 1997 r. rozpoczęto leczenie hormonalne tamoksyfenem w dawce 20 mg/d, trwające do 19 sierpnia 1997 r. W czasie leczenia wystąpiły objawy złej tolerancji leku w postaci nawracających dreszczy całego ciała, świądu skóry, wysypki, zawrotów głowy i uderzeń gorąca. Z tego powodu zmieniano lek na nolvadex $20 \mathrm{mg} / \mathrm{dz}$., a następnie zitazonium 20 mg/dz. Podczas stosowania każdego z nich opisane powyżej objawy powracały z różnym nasileniem, dlatego po 11 miesiącach odstąpiono od kontynuowania hormonoterapii.

W okresie leczenia i obserwacji po jego ukończeniu do roku 2007 u chorej monitorowano poziomy markerów CEA i Ca 15.3, których wartości mieściły się w granicach normy. Podobnie w wykonywanych kontrolnych badaniach USG piersi i RTG klatki piersiowej nie stwierdzano cech nawrotu choroby. We wrześniu 1998 r. pacjentka zgłaszała bóle piersi o niewielkim nasileniu. W badaniach obrazowych nie stwierdzono podejrzanych zmian w piersi. W listopadzie 1998 r. zaobserwowano wciągnięcie brodawki sutkowej. Ultrasonograficznie stwierdzono w piersi lewej tkankę gruczołową zmienioną przez bliznę z cechami obrzęku, bez podejrzanych ognisk. Węzły chłonne były niepowiększone. Markery w normie. Brak było wskazań do wykonania BAC.

W czerwcu 1999 r. w badaniu USG piersi lewej na godz. 10., dwa centymetry od brodawki, na głębokości 18-20 mm stwierdzono obszar hiperplazji przewodowej. Klinicznie zmiana była wyczuwalna jako przyotoczkowe zgrubienie $2 \times 1 \mathrm{~cm}$. W wykonanej mammografii stwierdzono utkanie gruczołowo-włókniste miąższu piersi lewej bez obrazów podejrzanych o złośliwość. Pacjentka była w tym okresie regularnie kontrolowana oraz oceniana mammograficznie. W grudniu 1999 r. pojawił się stan zapalny w skórze lewego dołu pachowego, który leczony był antybiotykiem. Zaczerwienienie utrzymywało się przez okres 6 miesięcy do czerwca 2000 roku. W latach 2000-2013 chora czuła się dobrze i nie zgłaszała się na badania kontrolne.

Po 16 latach obserwacji chora ponownie zgłosiła się w lipcu 2013 r. z powodu krwiaka w tkance podskórnej piersi lewej, który w ocenie chorej powstał po wykonanej kontrolnej mammografii. Dwukrotne badanie USG wykazało krwiaki w tkance podskórnej. W wykonanej biopsji cienkoigłowej nie stwierdzono obecności komórek nowotworowych. W badaniu klinicznym pierś lewa była powiększona i obrzęknięta, a w kwadrantach wewnętrznych stwierdzono naczyniakowate zmiany o nieregularnym zarysie, które nakłuto, uzyskując niewielką ilość treści krwistej, potwierdzoną badaniem mikroskopowym. Okoliczne węzły chłonne były niepowiększone. Miesiąc później, w sierpniu 2013 r. chora zgłosiła się z powodu stanu zapalnego piersi lewej, któremu towarzyszył krwiak wokół brodawki, powstały samoistnie. W pobranym wycinku z piersi lewej w dniu 2 września 2013 r. rozpoznano utkanie angiosarcoma G2?, G3?, CD 31 (+++), CD 34( ++), SMA (-), CK AE 1/AE3(-), Cd 30(-), Ki-67ok. 60-70\%, IM - 10/10 dpw.

Ze względu na rozpoznanie mikroskopowe w dniu 2 października 2013 r. wykonano prostą mastektomię lewej piersi (ryc. 1 i 2) oraz usunięto protezę po stronie prawej. Przebieg pooperacyjny był niepowikłany. W ocenie makroskopowej stwierdzono: na granicy kwadrantów wewnętrznych zlokalizowany głównie w skórze właściwej i naciekający miąższ sutka sino-wiśniowy, kruchy, lito-torbielowaty guz o wymiarach $9 \times 7$ cm grubości 1,6cm, uwypuklający naskórek w części centralnej z jego owrzodzeniem. Na obwodzie guza ognisko satelitarne 0,7 cm. Guz naciekał brodawkę sutkową. W badaniu mikroskopowym stwierdzono utkanie angiosarcoma G3. Pola lite (wrzecionowatokomórkowe) zajmowały nieco ponad 50\% masy guza, IM - 8/10 dpw. Wokół silikonowej protezy piersi prawej szkliwienie i zwapnienia. CD34(++), CD 31 (+++), Ki-67 — około 40\%.

W związku z wynikiem mikroskopowym chora została poddana ścisłej obserwacji. Pacjentka zgłasza się na badania kontrolne regularnie, dotąd nie stwierdzono żadnych niepokojących zmian w obszarze leczonym mięsakonaczyniaka.

\section{Omówienie}

Jako pierwszy - mięsaka typu angiosarcoma u chorej z zaawansowanym, przewlekłym obrzękiem limfatycznym ramienia opisał w1906 r. Lowenstein [3].W następnym roku zostały opisane przez Bormana trzy typy angiosarcoma: 


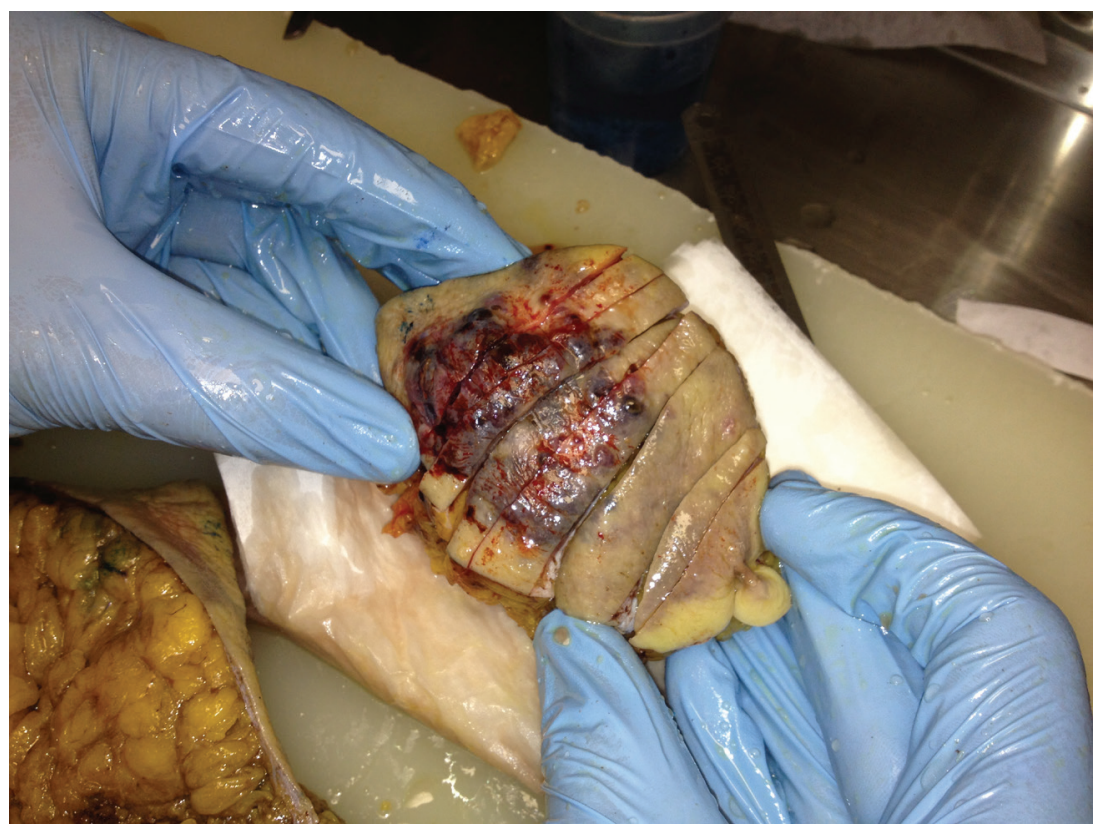

Rycina 1. Obraz makroskopowy angiosarcoma piersi lewej

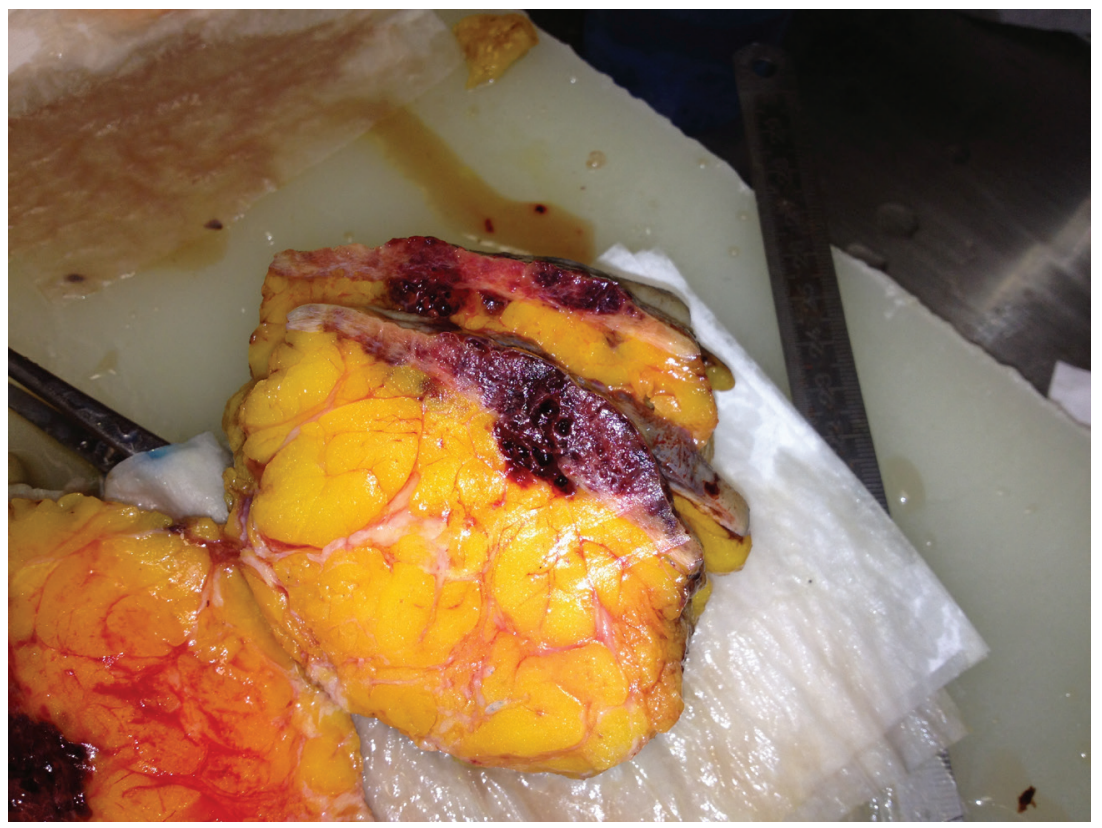

Rycina 2. Przekrój poprzeczny przez guz, zajmujący głównie skórę i częściowo tkankę tłuszczową

1. składający się z kanałów naczyniowych penetrujących tkankę tłuszczową piersi i miąższ, z brakiem proliferacji lub proliferacją małą, wewnątrznaczyniową, 2. zawierający lite ogniska i brodawkowy wewnatrznaczyniowy komponent, 3. czysty wzrost mięsaka z obfitym litym komponentem, martwicą i zmianami krwotocznymi [4]. Naczyniakomięsaki odznaczają się znaczną heterogennością zarówno w swej budowie mikroskopowej, jak i w przebiegu klinicznym. Nowotwory te rozwijają się z komórek śródbłonka lub różni- cują się w ich kierunku. Mogą się rozwinąć w każdej części ciała, 2/3 przypadków rozwija się w skórze głowy i szyi, a 1/4 w tkankach miękkich. W większości przypadków wystąpienie choroby jest poprzedzone obrzękiem chłonnym, a klasyczną postacią jest zespół Stewarta-Trevesa, pojawiający się najczęściej po radykalnej mastektomii [5].

Chorzy napromieniani mają większe ryzyko zachorowania na AS, który rozpoznany w polu napromienianym stanowi 3-10\% wszystkich zachorowań. Największa zapadalność 
na AS wskutek przebytej radioterapii występuje 5-10 lat po zakończeniu leczenia. Szczególnie zagrożeni są chorzy poddawani radioterapii z powodu raka piersi i chłoniaków [6-8]. Zachorowanie na AS nie wiąże się z żadnym szczególnym zespołem genetycznym, a także rzadko jest skutkiem występowania dziedzicznych zespołów predysponujących. Jednakże u ok 3\% chorych na AS stwierdzane są zachorowania na: retinoblastomę, zespółvon Recklinghausena, chorobę Olliera (mnogie wyrośla chrzęstne), chorobę Maffucciego (mnogie chrzęstniaki wewnątrzkostne oraz naczyniaki skóry) lub xerodermię pigmentosum [9-13].

Badania molekularne u chorych na AS wykazują nadekspresję VEGF-A u 85-94\% badanych i odpowiednio VEGF-C (12-88\%), VEGFR-1 (94\%), VEGFR-2 (65\%), VEGFR-3 (79\%). Utrata zdolności do ekspresji VEGFR-2 wiąże się z gorszym rokowaniem [14,15]. Antonescu i wsp. stwierdzili silną ekspresję $K D R$ (kinase domain region) w pierwotnych naczyniakomięsakach piersi, niezależnie od tego, czy chore były wcześniej napromieniane, czy nie. Sekwencjonowanie genu KDR pozwoliło na zidentyfikowanie $10 \%$ chorych z jego mutacją. W badaniach in vitro zmutowane formy $K D R$ są wrażliwe na stosowanie inhibitorów kinazy, takich jak sorafenib [16]. Molekularna analiza genu p53 wskazała na jego mutację u 11-52\% chorych na AS. Badania Zietza i wsp. wykazały zwiększoną ilość białek MDM2 u 68\% chorych na AS. Zwiększenie ekspresji p53 i białek MDM2 wiązało się ze zwiększoną ekspresją VEGF stwierdzaną u 80\% pacjentów $[17,18]$.

W 1987 r. Body i wsp. opisali wtórny nowotwór skórny o typie angiosarcoma w obszarze napromienianym z powodu raka piersi. Autorzy szwedzcy - Styring i wsp. — w 2010 r. opublikowali wyniki obserwacji chorych z rozpoznanymi mięsakami typu angiosarcoma po radioterapii z powodu raka piersi. Wyróżnili oni dwie grupy: chore po mastektomii radykalnej i radioterapii z zespołem Stewarta-Trevesa oraz chore po leczeniu oszczędzającym z obecnym angiosarcoma w rejonie pól napromienianych [3].

Powstanie AS może być wiązane z oddziaływaniem czynników środowiskowych, i wówczas nowotwór zaliczany jest do guzów wtórnych, lub może powstawać bez ich udziału, i określony jest jako pierwotny [4]. Zachorowania na AS w wątrobie mają udokumentowane źródło powstania i są wynikiem narażenia zawodowego na polichlorek winylu (PVC) i dwutlenek toru używany w radiologii lub powstają w wyniku kontaktu z innymi karcynogenami, np. arsen, będący składnikiem środków owadobójczych $[9,11]$.

AS opisywany był w tkankach miękkich, piersi, płucach, prostacie, odbytnicy, jajniku, macicy, na skórze twarzy, owłosionej głowy i w wątrobie. Postacie pierwotne tego nowotworu opisywane są przede wszystkim u młodych kobiet, natomiast postacie wtórne - u kobiet po 60 r.ż. [5,19]. Opisana chora w chwili rozpoznania miała 71 lat. Postaci wtórnej AS, powstałej po radioterapii, przypisuje się rozwój zmian powierzchownych w skórze. W ocenie Kunkela i wsp. tak powstały nowotwór ma krótszy czas utajenia, nie ma związku z obrzękiem limfatycznym [20]. W literaturze opisywane są również przypadki występowania angiosarcoma i obrzęku limfatycznego pod postacią zespołu StewartaTrevesa po EBRT [21].

Do istotnych czynników prognostycznych dla AS zalicza się: wielkość guza, umiejscowienie względem powięzi, indeks mitotyczny, stan marginesów operacyjnych, sposoby leczenia i wiek chorego. Zostały one określone na podstawie danych z niewielkich liczebnie grup chorych, dlatego wymagają dalszych badań [17, 20, 22, 23].

Nowotwór ten długo przebiega w sposób bezobjawowy. Okresy utajenia według różnych autorów wahają się od 3 do 25 lat $[2,24,25]$. Autorzy wskazują na brak patognomonicznych cech radiologicznych, pozwalających rozpoznać angiosarcoma w badaniu USG czy MMG. W obu tych badaniach zmiany związane z AS prezentowane są jako niejednoznaczne, o nieostrych zarysach, które są charakterystyczne dla rozpoznania raka piersi. Rezonans magnetyczny (MRI) jest lepszym badaniem diagnostycznym, bowiem ujawnia uszkodzone naczynia krwionośne i otaczające tkanki [26-29]. Rozpoznanie tego nowotworu opiera się na wyniku badania mikroskopowego po biopsji gruboigłowej lub biopsji otwartej z pobraniem wycinków [3]. Dużym utrudnieniem w rozpoznaniu tego nowotworu jest fakt, iż przybiera on różne formy: wieloogniskowych guzków barwy niebiesko-wiśniowej, zmian podobnych do naczyniaków, nieregularnych form, obrzęku [2].

Podstawą leczenia jest szerokie wycięcie en bloc.W przypadku pierwotnych AS zlokalizowanych w piersi lub w tkankach miękkich stosunkowo łatwo (w ok. 85\% przypadków) udaje się uzyskać marginesy chirurgiczne wolne od utkania nowotworu [13, 17, 30-32].

Radykalna operacja (R0) daje szansę całkowitego wyleczenia. W przypadku omawianej chorej udało się usunąć guz w całości i uzyskać szerokie marginesy.

W większości przypadków w AS stosuje się pooperacyjną radioterapię (EBRT) [33, 34].

Wielu autorów zaleca takie postępowanie po wycięciu zmiany, mimo iż musi ona być prowadzona w obszarze wcześniej napromienianym. Brakuje danych potwierdzających rolę uzupełniającej chemioterapii u chorych na angiosarcoma, pomimo iż u 50\% chorych występują przerzuty w narządach odległych $[9,11,12,18,22,30,32,35]$.

W związku z nadekspresją czynników angiogennych stwierdzaną u chorych na AS największe nadzieje w leczeniu systemowym mięsaków tkanek miękkich wiąże się ze stosowaniem leków celowanych molekularnie. Badania oceniające aktywność sorafenibu, wielokierunkowego inhibitora kinazy tyrozynowej RAF i VEGFR, wykazały zróżnicowane odsetki odpowiedzi na leczenie, od 0 do 14\%. Podobnie odpowiedzi na leczenie imatynibem chorych z uogólnioną postacią nie są satysfakcjonujące i wynoszą ok. 12\% [35]. 
Chorzy operowani żyją dłużej — średnio ok. 34 miesiące (6-84) w stosunku do nieoperowanych, żyjących średnio ok. 6 miesięcy (5-24). Czas przeżycia wolny od choroby (DFS) oceniany jest na ok. 16 miesięcy, czas przeżycia specyficzny (DSS) dla choroby wynosi ok. 37 miesięcy. Nawet po całkowitej resekcji (R0) u 70\% chorych stwierdza się wznowy miejscowe, a u 50\% występują przerzuty odległe [24]. Przeżycia specyficzne (DSS) dla choroby wynoszą ok. 3 lat. Jest wiele prób stosowania cytostatyków, jednakże ze względu na rzadkość nowotworu i nieliczne grupy chorych ich efekt jest trudny do oceny. Leczenie antyangiogenne jest wyłącznie stosowane w badaniach klinicznych. Są również próby powtórnego napromieniania w mniejszych dawkach i łączenia go z hypertermią [25].

Bez względu na sposób leczenia rokowanie co do przeżycia jest zawsze bardzo poważne. Trwają intensywne badania, których celem jest opracowaniem nowych leków nakierowanych na specyficzne, uszkodzone w komórkach mięsaków szlaki przemian molekularnych, które w świetle badań stanowią podstawowe etiopatogenetyczne przyczyny powstawania i progresji danego nowotworu.

\section{Konflikt interesu: nie zgłoszono}

\section{Dr n. med. Zbigniew Jodkiewicz}

Pracownia Przygotowania, Planowania i Leczenia Napromienianiem w Zakładzie Teleradioterapii

Centrum Onkologii - Instytut im. Marii Skłodowskiej-Curie

ul. Wawelska 15, 02-061 Warszawa

e-mail:zbigniew_jodkiewicz@onet.eu

Otrzymano: 4 lutego $2014 \mathrm{r}$.

Przyjęto do druku: 6 maja 2014 r.

\section{Piśmiennictwo}

1. Ducimetiere F, Lurkin A, Ranchere-Vince D i wsp. Incidence of sarcoma histotypes and molecular subtypes in a prospective epidemiological study with central pathology review and molecular testing. PLoS One 6 (8) www.plosone.org/articl/info journal.pone.0020294. pobrano 20.01.2014r.

2. Nakumura R, Nagashima T, Sakakibara M i wsp. Angiosarcoma arising in the breast following breast - conserving surgery with radiation for breast. Breast Cancer 2007; 14: 245-249.

3. Styring E, Fernebo J, Jonsson PE i wsp. Changing clinical presentation of angiosarcomas after breast cancer: from late tumors in edematousarms to erlier tumors on the thoracic wall. Breast Cancer Res Treat 2010; 122: 883-887.

4. Kaklamanos IG, Birbas K, Syrigos KN i wsp. Breast angiosarcoma that is not related to radiation exposure: a comprehensive review of the literature. Surg Today 2011; 41: 163-168.

5. Stewart FW, Treves N. Lymphangiosarcoma in post mastectomy lymphedema; a report of six cases in elephantiasis chirurgica. Cancer 1948; 1: 64-81.

6. Yap J, Chuba PJ, Thomas R i wsp. Sarcoma as a second malignancy after treatment for breast cancer. Int J Radiat Oncol Biol Phys 2002; 52: 1231-1237.

7. Huang J, Mackillop WJ. Increased risk of soft tissue sarcoma after radiotherapy in women with breast carcinoma. Cancer 2001; 92: $172-180$.
8. Virtanen A, Pukkala E, Auvinen A. Angiosarcoma after radiotherapy: a cohort study of 332163 Finnish cancer patients. Br JCancer 2007; 97: 115-117.

9. Penel N, Marréaud S, Robin Y i wsp. Angiosarcoma: state of the art and perspectives. Crit Rev Oncol Hematol 2011; 80: 257-263.

10. Thomas LB, Popper H. Pathology of angiosarcoma of the liver among vinyl chloride - polyvinyl chloride workers. Ann N Y Acad Sci 1975; 246: 268-277.

11. Young RJ, Brown NJ, Reed MW i wsp. Angiosarcoma. Lancet Oncol 2010; 11: 983-991.

12. Fury MG, Antonescu CR, Van Zee KJ i wsp. A 14-year retrospective review of angiosarcoma: clinical characteristics, prognostic factors, and treatment outcomes with surgery and chemotherapy. Cancer 2005; 11: 241-247.

13. Penel N, Grosjean J, Robin YM i wsp. Frequency of certain established risk factors in soft tissue sarcomas in adults: a prospective descriptive study of 658 cases. Sarcoma 2008; 2008: ID 459386.

14. Itakura $\mathrm{E}$, Yamamoto $\mathrm{H}, \mathrm{Oda} \mathrm{Y}$ i wsp. Detection and characterization of vascular endothelial growth factors and their receptors in a series of angiosarcomas. J Surg Oncol 2008; 97: 74-81.

15. Lahat G, Dhuka AR, Hallevi H i wsp. Angiosarcoma: clinical and molecular insights. Ann Surg 2010; 251: 1098-1106.

16. Antonescu CR, Yoshida A, Guo T i wsp. KDR activating mutations in human angiosarcomas are sensitive to specific kinase inhibitors. Cancer Res 2009; 69: 7175-7179.

17. Naka N, Ohsawa M, Tomita Y i wsp. Prognostic factors in angiosarcoma: a multivariate analysis of 55 cases. J Surg Oncol 1996; 61: 170-176.

18. Zietz C, Rössle M, Haas C i wsp. MDM-2 oncoprotein overexpression, p53 gene mutation, and VEGF up-regulation in angiosarcomas. Am J Pathol 1998; 153: 1425-1433.

19. Ortega A, Gil JM, Urruticoetxea A i wsp. Angiosarcoma of the breast. Two cases following breast conserving treatment for invasive carcinoma. Clin Transl Oncol 2006; 8: 536-539.

20. Budd GT. Management of Angiosarcoma. Curr Oncol Rep 2002;4:515-519.

21. Kunkel T, Mylonas J, Mayr D i wsp. Recurrence of secondary angiosarcoma in patient with post-radiated breast for breast cancer. Arch Gynecol Obstet 2008; 278: 497-501.

22. Morgan MB, Swann M, Somach S i wsp. Cutaneous angiosarcoma: a case series with prognostic correlation. J Am Acad Dermatol 2004; 50: 867-874

23. Meis-Kindblom JM, Kindblom LG. Angiosarcoma of soft tissue: a study of 80 cases. Am J Surg Pathol 1998; 22: 683-697.

24. Seinen JM, Styring E, Verstoppen V i wsp. Radiation-associated angiocarcinoma after breast cancer : high reccurence rate and poor survival despite surgical treatment with R0 resection. Ann Surg Oncol 2012; 19: $2700-2706$.

25. Linthorstn M, van Geel AN, Baartman EA i wsp. Effect of a combined surgery, re-irradiation and hyperthermia therapy on local controlrate in radio-induced angiosarcoma of the chest wall. Strahlenter Onkol 2013; 189: 387-393.

26. Yang WT. Mammary angiosarcoma imaging findings in 24 patients. Radiology 2007; 242: 725-734.

27. Palm S. What is Breast Cancer? Angiosarcoma. American Cancer Society. Revised : 09/13/2007. http://breastcancer.about.com/od/types/p/angiosarcoma.htm pobrano 21.01.2014r.

28. Farrokh D, Hashemi J, Zand B i wsp. Angiosarcoma of the breast: report of a case and literature review. Iran J of Radiology, Winter 2006; 3: 81-84.

29. Monroe AT, Feigenberg SJ, Mendenhall NP. Angiosarcoma after breast - conserving therapy. Cancer 2003; 97: 1832-1840.

30. Fayette J, Martin E. Piperno-Neumann S i wsp. Angiosarcomas, a heterogeneous group of sarcomas with specific behavior depending on primary site: a retrospective study of 161 cases. Ann Oncol 2007; 18: 2030-2036.

31. Pawlik TM, Paulino AF, McGinn CJ i wsp. Cutaneous angiosarcoma of the scalp: a multidisciplinary approach. Cancer 2003; 98: 1716-1726.

32. Abraham JA, Hornicek FJ, Kaufman AM i wsp. Treatment and outcome of 82 patients with angiosarcoma. Ann Surg Oncol 2007; 14: 1953-1967.

33. Mark RJ, Poen JC, Tran LM. Angiosarcoma. A report of 67 patients and a review of the literature. Cancer 1996; 77: 2400-2406.

34. Maddox JC, Evans HL. Angiosarcoma of skin and soft tissue: a study of forty-four cases. Cancer 1981; 48: 1907-1921.

35. Maki RG, D'Adamo DR, Keohan ML i wsp. Phase II study of sorafenib in patients with metastatic or recurrent sarcomas. J Clin Oncol 2009; 27: 3133-3140. 